\title{
Masa Depan Bisnis Kreatif Diera Revolusi Industri 4.0 Ditinjau Dari Kebijakan Sektor Publik, Bisnis Dan Perpajakan
}

\author{
T. Syahrul Reza ${ }^{1)}$, Wawan Hermawansyah ${ }^{2)}$ \\ Fakultas Ilmu Administrasi Insitut STIAMI \\ Email : ts.reza@stiami.ac.id
}

\begin{tabular}{|c|c|}
\hline ARTICLE INFO & $A B S T R A C T$ \\
\hline Keywords: & $\begin{array}{l}\text { Di era digital ini akan membuat semua orang berfikir untuk bisa memanfaatkan dunia } \\
\text { internet yang memiliki target sangat luas. Namun jika salah langkah dalam mengambil }\end{array}$ \\
\hline $\begin{array}{l}\text { Bisnis Kreatif, } \\
\text { digital, } \\
\text { diskrupsi, } \\
\text { ekonomi. }\end{array}$ & $\begin{array}{l}\text { bisnis yang tidak cocok, bisa jadi akan rugi. Apalagi jika tidak memilah-milah terlebih } \\
\text { dahulu, pasti akan tertipu nantinya, karena sekarang ini semakin marak dunia } \\
\text { penipuan. Digital preneur dapat diartikan sebagai kumpulan aktivitas ekonomi yang } \\
\text { terkait dengan penciptaan atau penggunaan pengetahuan dan informasi serta } \\
\text { keterampilan dan bakat individu untuk menciptakan kesejahteraan serta lapangan } \\
\text { pekerjaan dengan menghasilkan dan mengeksploitasi daya kreasi dan daya cipta } \\
\text { individu.Salah satu digital preneur adalah bisnis online. Bisnis online saat ini bukan } \\
\text { lagi menjadi sesuatu yang asing bagi kita terutama bagi kaum millennial baik yang di } \\
\text { Indonesia maupun internasional, baik kita yang kesehariannya terbiasa menggunakan } \\
\text { internet ataupun tidak, untuk saat ini digital preneur memiliki prospek yang cukup } \\
\text { besar dimana pada masa ini hampir semua orang menginginkan kepraktisan dan } \\
\text { kemudahan dalam hal memenuhi kebutuhan. Praktis adalah salah satu cirri khas dari } \\
\text { bisnis online dimana transaksi bisnis online dapat dilakukan tanpa bertatap muka atau } \\
\text { bahkan tidak saling kenal sebelumnya.. }\end{array}$ \\
\hline
\end{tabular}

\section{PENDAHULUAN}

Perjalanan step Revolusi Industri saat ini telah masuk pada step Revolusi industry 4.0, lebih dikenal dengan istilah revolusi digital. Sebuah kondisi perubahan yang signifikan terhadap keberadaan sebuah teknologi yang dinamakan "internet".dukungan akan ketersediaan hard-ware dan soft-ware dengan multi pilihan ikut menyumbang percepatan dampak domino dari keberadaan teknologi ini, yang lebih banyak di sebut dengan generasi internet of thing (IOT). Perjalanan revolusi industri 4.0 ini tidak lepas dari revolusi industry sebelumnya, yakni Revolusi industry 3, 2 dan 1. Menteri Perindustrian Airlangga Hartato dalam sebuah kesempatan menyampaikan sejatinya revolusi industri ini dimulai sejak zaman pemerintahan HindiaBelanda. Saat itu, revolusi industri pertama hadir dalam konteks steam engine atau mesin uap."Kemudian revolusi industri kedua pada saat otomotif general fort membuat line production Indonesia masih jaman hinda-Belanda. Nah revolusi industri ketiga diawali di tahun 90-an itu dengan mulai otomatisasi dan pada watu itu terjadi globalisasi,"

Pada revolusi industri generasi 4.0, manusia telah menemukan pola baru ketika disruptif teknologi hadir begitu cepat dan mengancam keberadaan perusahaan-perusahaan incumbent. Sejarah telah mencatat bahwa revolusi industri telah banyak menelan korban dengan matinya perusahaan-perusahaan raksasa.

Lebih dari itu, pada era industri generasi 4.0 ini, ukuran besar perusahaan tidak menjadi jaminan, namun kelincahan perusahaan menjadi kunci keberhasilan meraih prestasi dengan cepat. Hal ini ditunjukkan oleh Uber yang mengancam pemain-pemain besar pada industri transportasi di seluruh dunia atau Airbnb yang mengancam pemain-pemain utama di industri jasa pariwisata. Ini membuktikan bahwa yang cepat dapat memangsa yang lambat dan bukan yang besar memangsa yang kecil.

Yang sangat menarik dari semua ini adalah meningkatnya pemain-pemain baru (new commers) dalam bisnis kreatif seperti 4 bidang yang dominan, yaitu bidang : kuliner, fashion, Kriya dan aplikasi multimedia (sumber : bekraf 2015), yang diisi oleh pelaku-plekau bisnia anak-anak usia produktif yang kreatif . hal ini terjadi karena mudahnya akses dan transfer knowledge dengan menggunakan fasilitas search engine (google) dan lainnya. Menurut data becraft tahun 2018, bahwa sumbangsih bisnis creative ini telah menyumbang Kontribusi bisnis ekonomi kreatif (Bekraf) lebih dari 1000 Triliun (sumber kompas.com 25 
september 2018) dengan pelaku bisnis dominan dilakukan antara umur 25-59 sebesar 75.4\%. artinya saat ini semua orang bisa melakukan bisnis, tanpa harus memiliki modal dan asset besar, seseorang yang memiliki ide creative dengan mudah dapat ditemukan oleh kelompok orang yang memiliki asset modal pertemuan mereka dilakukan di dunia maya dengan cepat dan praktis, kuncinya adalah kreativ dan inovatif. Era industri 4.0 ditandai konektivitas dan interaksi melalui teknologi informasi dan komunikasi yang terintegrasi. Konektivitas dan digitalisasi itu membuat nilai rantai manufaktur lebih efisien dan kualitas produknya meningkat.

\section{LANDASAN TEORI}

\section{Disruption}

Disruption adalah sebuah inovasi, inilah inovasi yang akan menggantikan seluruh sistem lama dengan cara-cara baru. Disruption berpotensi menggantikan pemain-pemain lama dengan yang baru. disruption menggantikan teknologi lama yang serba fisik dengan teknologi digital yang menghasilkan sesuatu yang benar-benar baru dan lebih efesien. Menurut Clayton Christensen, Discruption menggantikan pasar lama, industry dan teknologi dan menghasilkan sesuatu kebaruan yang lebih efesien dan menyeluruh. Ia bersifat destructive dan creative. Menurut Mark Zucherberg (founder FB) mengatakan bahwa "sukses tergantung pada kemampuan kita menyelaraskan ketiganya : iteration, innovation dan discruption. "jika anda tidak mendisrupsi diri sendiri, anda akan mendapatkan dalam bentuk 'hadiah' dari orang lain."

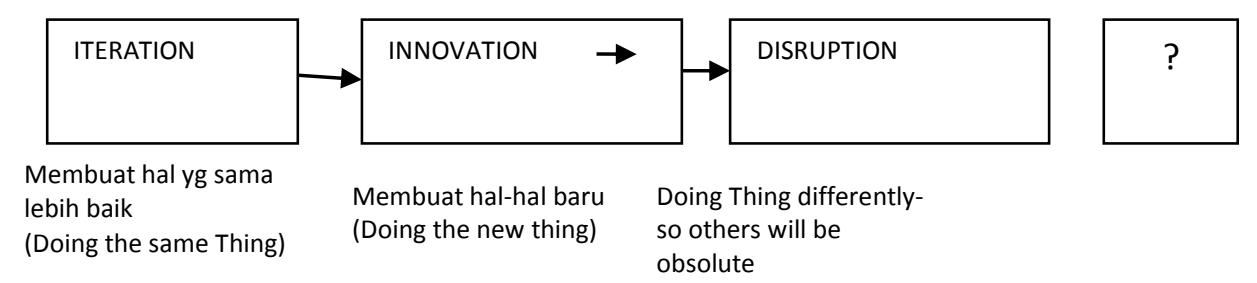

\section{Transfer Knowledge dan Keterbukaan Informasi}

Tidak heran saat ini jika makin banyak pendatang-pendatang baru usia produktif masuk dalam kancah bisnis kreatif, karena begitu mudah saat ini setiap orang untuk mencari dan melihat sekaligus belajar tentang kesuksesan orang lain dalam menjalankan bisnisnya. Makin maraknya aplikasi mesin pencarian di internet dengan tampilan data / informasi dalam bentuk image dan animasi (video), menjadikan trigger bagi pemula untuk mencari model dan cara berbisnis, ini semua sangat mudah dilakukan.

Makna Transfer Knowledge artinya sangat mudah siapapun, bahkan pemula sekalipun untuk mempelajari beberapa teknik ilmu pengetahuan menjalankan bisnis tertentu, sampai dapat mencari dengan mudah informasi pangsa pasar.

Dorongan keingintahuan yang tinggi, menjadikan meningkatnya ide-ide kreatif dan inovatif. Dapat belajar dengan cepat dari kegagalan dan bahkan keberhasilan orang lain dalam berbisnis. Kenapa ide kreatif dan inovativ itu saat ini cendrung meningkat? Karena setiap orang saat ini sadar bahwa semakin meningkatnya kemudahan belajar dan transparansi informasi, maka pesaing akan makin meningkat dan kompetitif serta konsumen semakin cerdas memilih produk yang dibeli.

\section{Bisnis Kreatif}

Menurut Zimmerer dkk (2009) kretifitas merupakan kemampuan untuk mengembangkan ide-ide baru dan untuk menemukan cara-cara baru dalam melihat masalah dan peluang. Inovasi adalah kemampuan untuk menerapkan solusi kreatif terhadap masalah dan peluang untuk meningkatkan dan untuk memperkaya kehidupan orang-orang . jadi kreatif merupakan sifat mencari cara-cara baru dan inovatif adalah sifat yang menerapkan solusi kreatif. Pengusaha muda sangat berpeluang meraih kesempatan bisnis dalam revolusi industri 4.0, terutama pada sektor-sektor berbasis teknologi digital. Pengusaha muda yang bertalenta, kreatif, dan inovatif akan diuntungkan oleh gelombang revolusi industri keempat ini. (Suara Pembaruan, april 2018). Menteri Perindustrian (Menperin) Airlangga Hartarto mengatakan, pemerintah telah menyiapkan 1-2 subsektor industri unggulan dari lima sektor yang telah ditentukan dalam peta jalan industri 4.0 (Making Indonesia 4.0) yang baru diluncurkan pemerintah, sehingga dapat mendorong industri lainnya. Hal ini merupakan angin segar buat pelaku-pelaku baru bisnis creative sekaligus merupakan sinyal waspada bagi 
pemain lama, karena faktanya pergerakan pertumbuhan new commer pembisnis ini disektor bisnis creative sangat cepat.

Setidaknya ada 4 faktor yang menjadi pendorong tumbuhnya pelaku-pelaku baru bisnis creative, yaitu : (1) dukungan dan ketersediaan Teknology sangat tinggi, (2) proses transfer knowledge (keterbukaan ilmu) bagi info kesuksesan bisnis (best practice) sangat cepat dan mudah dipelajari, (3) proses penghubung antara supplier dan produsen sangat cepat di pertemukan (secara online) dan (4) kemudahan melakukan pemasaran (digital marketing).

Hal ini bukan hanya isapan "jempol" saja, faktanya menurut data becraf Indonesia tahun 2015, eksistensi bisnis kreatif telah menyumbang PDB sebesar 852 Triliun rupiah (memberikan kontribusi sekitar 7,38 persen terhadap total perekonomian nasional). Dengan makin berkembangnya bisnis kreatif di Indonesia, keseimbangan bisnis pun semakin tercipta, artinya pelaku-pelaku bisnis dapat dilakukan oleh semua lapisan masyarakat dan sebaran wilayah di daerah-daerah. Berikut beberapa padanan data statistic bersumber dari becraf Indonesia tahun 2015 , sebagai berikut :

a. Trend tenaga kerja bekraf sebanyak 15.959 .590 orang dari keseluruhan tenaga kerja Indonesia sebanyak 114.819.199 orang, dengan persentase tenaga bisnis ekonomi creative di Asia Tenggara sebesar 43\%.

b. Struktur Tenaga beKraf di dominasi anak muda (usia produktif) sebesar $75.4 \%$, dengan struktur pendidikan pada level SMA sederajat sebesar $75 \%$, ini menunjukan ke depan akan semakin menarik pertumbuhan bisnis ekraf karena didominasi usia kaum muda.

c. Kontribusi Subsector utama bisnis creative adalah sektor Kuliner $(41,69 \%)$, Fashion $(18,15 \%)$, dan Kriya $(15,70 \%)$

d. Akses Permodalan bisnis ecraf , Modal sendiri $=92,37 \%$, Pinjaman Bank $=24,44 \%$ dan modal venture $=$ $0,66 \%$. Peluang makin berkembang bisnis ekonomi kreatif akan tinggi, salah satu pemicunya adalah dengan permodalan individu saja bisnis dapat berjalan dengan baik.

e. Daerah pemasaran : dalam kota $/ \mathrm{Kab}=97,36 \%$, luar kota $=10,23 \%$ dan luar negeri $=8,41 \%$

f. Media promosi $=$ Media social $=53,72 \%$, website $=28,25 \%$, brosur $=28,04 \%$, pameran $=24,14 \%$ dan lainnya $=23,88 \%$.

g. Asal bahan baku produksi : Domestik dari dalam kabupaten $/$ kota $=82,69 \%$, Domestik dari luar Kota $/$ kab $=55,86 \%$, luar negeri $=5,71 \%$

\section{Pemberdayaan Ekonomi Lokal}

Data statistik bekraf Indonesia tahun 2015, terlihat bahwa perputaran produksi bisnis ekonomi kreatif (bekraft) mulai dari sumber bahan baku sampai pada tahap pemasaran didominasi internal daerah setempat (pemasaran dalam kota/kab $=97,36 \%$, asal bahan baku produksi domestic dari dalam $\mathrm{kota} / \mathrm{kab}=82,69 \%$, ini artinya tingkat kearifan local akan meningkat serta pangsa pasar internal sangat besar.

Kondisi tersebut di atas secara otomatis akan meningkatkan pertumbuhan ekonomi wilayah meningkat secara cepat dan merata.

\section{Era digital market}

Perkembangan teknologi ke arah serba digital saat ini semakin pesat. Pada era digital seperti ini, manusia secara umum memiliki gaya hidup baru yang tidak bisa dilepaskan dari perangkat yang serba elektronik. Teknologi menjadi alat yang mampu membantu sebagian besar kebutuhan manusia.

Era digital telah membawa berbagai perubahan yang baik sebagai dampak positif yang bisa gunakan sebaik-baiknya. Namun dalam waktu yang bersamaan, era digital juga membawa banyak dampak negatif, sehingga menjadi tantangan baru dalam kehidupan manusia di era digital ini.

New world dengan cepat dapat terbentuk akibat dari era digital yang masuk ke semua segmen kehidupan. New world : digital_Marketplace, sebuah area pasar yang di dorong oleh digitalisasi dengan konsep tidak ada batas waktu dan tempat. Konsep market baru yang berbeda dengan konsep sebelumnya, dimana dulu valuasi dari perusahaan dilihat dari apa yang diperdagangkan, namun sekarang valuasi perusahaan diawali dari bagaimana membangun ekologi yang dulu disebut "pasar".

T. Syahrul Reza, et.al.( Masa Depan Bisnis Kreatif Diera Revolusi Industri 4.0 Ditinjau Dari...) 
Gurley (2012) setidaknya ada 10 persyaratan agar digital market_place dapat terbentuk, yaitu : pertama, apakah marketplace yang dikembangkan memenuhi tujuan mudah dan efesiensi?, kedua, apakah marketplace mampu memberikan value yang lebih besar dari yang sudah ada?, ketiga, apakah marketplace ini memanfaatkan teknologi yang menjamin efesiensi?,keeempat, apakah marketplace mampu mengkonsolidasi pasar yang terfragmentasi?, Kelima, apakah marketplace ini mempermudah para pemasok untuk bergabung?, Keenam, apakah marketplace ini mampu melayani permintaan besar?, Ketujuh, apakah marketplace ini dapat diperluas penggunaannya, kedelapan,apakah marketplace ini mampu memenuhi kebutuhan harian ?, kesembilan, apakah marketplace ini mampu mengkonsolidasikan pembayaran? Dana kesepuluh, apakah marketplace ini mampu mendongkrak jejering?.

Kesepuluh hal pertanyaan di atas sepertinya telah dominan terpenuhi saat ini, karena di era Revolusi Industri 4.0 / generasi internet ke 3 kesepuluh persyaratan di atas sangat mudah terpenuhi, seperti munculnya beberapa situs market yang berperan dominan dalam mendukung proses transaksi market, khususnya bisnis ekonomi kreatif di Indonesia. Antara lain : Bukalapak.com, opentable,Kickstarter, kitabisa.com, Tokopedia, Go-Jek,Grab, IndonesiaX, YouTube, dll.

\section{Internet}

Berbicara hal tentang Internet, sepertinya semua orang sudah sangat familier baik secara definisi maupun secara penggunaannya. Semenjak awal tahun $2000 \mathrm{~s} / \mathrm{d}$ tahun 2005 perkembangan penggunaan internet di Indonesia sangat tinggi. Ditambah dengan diikuti dengan aktiv dan progressive oleh para produsen mobile teknologi (HP) dan sejenisnya dalam menyediakan Hardware dan software dalam penggunaan internet dengan model dan fungsi yang bervariatif.

Berikut sekilas data statistik dari APJII (asosiasi penyelenggara jasa internet Indonesia) terkait penggunaan internet di Indonesia, tahun 2017, sebagai berikut :

- Sebanyak 143 juta jiwa pengguna internet, dari total jumlah penduduk 262 juta (54,68\%).

- Pemanfaatan internet bidang ekonomi di dominasi untuk pengecekan harga $=45,14 \%$.

- $\quad$ komposisi pengguna internet berdasarkan level ekonomi: menengah ke bawah $=74,62 \%$, menengah ke atas $=16,02 \%$ sosial atas $=1,98 \%$, strata ekonomi bawah $=7,39 \%$.

- Pemanfaatan internet Berbasis Usia: 13-18 Tahun 75,50 \%, 19-34 Tahun =74,23\%, 35-54 tahun = $44,06 \%$ dan $>54$ tahun $=15,72 \%$.

Secara waktu yang relative cepat, masyarakat sekitar kita makin mahir dan cerdas dalam hal penggunaan dan pemanfaatan internet, baik untuk keperluan biasa sampai keperluan bisnis.

Perkembangan Internet saat ini tidak semata-mata langsung ada, namun melalui proses yang panjang. Seperti yang diramalkan Alvin Tofler (1980) "sebuah komunitas global elektronik saat manusia begitu mudah menjangkau segala jasa dan informasi tanpa batas dan membangun komunitasnya, Berinteraksi bukan berdasarkan jarak geografi melainkan karena kesamaan minat". Stave Case (2016)- pendiri AOL (America Online) membagi dunia internet menjadi 3 gelombang : Geombang Pertama (1985-1999) from zero to one Gelombang kedua $(2000$ - 2015) - Aplikasi dan komersialisasi, munculnya mesin pencarian data Google, jejaring social. Gelombang Ketiga (2016) - Era Internet Of Things, era ini merupakan era Deep net (dark net, hidden web).

\section{KESIMPULAN}

Revolusi industri 4.0 yang disebut juga dengan Revolusi digital dan pertumbuhan internet generasi ke 3 (IOT) telah membawa perubahan signipikan terhadap life-style pelaku bisnis. Kondisi ini telah mendorong dengan cepat pertumbuhan pendatang-pendatang baru bisnis, terutama sektor bisnis kreatif.

Kemudahan akses, keterbukaan informasi serta transfer-Knowledge saat ini banyak menjadi trigger bagi setiap orang untuk melakukan upaya kreatif dan inovasi. Dengan kata lain akan mendorong makin meningkatnya Disruption pada semua bidang, terutama bidang proses bisnis. Saat ini semua orang bisa melakukan bisnis tanpa harus memiliki modal besar dan ilmu yang tinggi (dari kampus) cukup mempelajari melalui sarana internet dengan media youTube, googling, flogger, web dll. 
Kondisi ini secara makro di Indonesia mendorong atmosfer perekonomian rakyat terutama di daerahdaerah, pada tahun 2015 saja bisnis ekonomi kreatif telah menyumbang PDB sekitar 800 Trilliun rupiah, terindikasi tiap tahun akan terus meningkat jumlahnya. Peningkatan ini disebabkan beberapa faktor, diantaranya, pertama tingkat keberpihakan Pemerintah terhadap pelaku bisnis ekonomi kreatif terus meningkat, dengan pemberdayaan UMKM di daerah-daerah. Kedua kecendrungan meningkatnya peran anak-anak muda untuk menjadi pelaku bisnis ekonomi kreatif dengan pemberdayaan kearifan local. Ketiga meningkatknya tingkat penggunaan internet setiap tahun khususnya di daerah-daerah.

\section{DAFTAR PUSTAKA}

Agarwal,PK. (2016). The Future of Jobs in a Discruption World. Silocon Valley: Northeastern University.

APJII, (2017). Data Penggunaan Internet 2018: www.Kominfo.go.id

Airlangga Hartanto, (2018) Revolusi Industri 4.0 : Suara Pembaruan

Bekraf (2015). Data Statistik bekraf Indonesia : http://beckaft.go.id

Christensen, Clayton M., \& Horn, Michael (2008). Disrupting Class: How Disruptive Innovation Will Change The Way The World Learns. New York : MCGraw-Hill

Gurley, Bill (2012). All Markets Are Not Created Equal: 10 Factors To Consider When Evaluating Digital Marketplace. http://abovethecrowd.com

Kasali, R (2014). Lets Change .jakarta :Gramedia

Kasali,R (2017). Disruption Jakarta : Gramedia 